\title{
Влияние вознаграждения топ-менеджмента и совета директоров на стоимость крупных российских компаний
}

\author{
Байбурина Э.P. ${ }^{35}$, Шустрова Е.В. ${ }^{36}$
}

В последнее время в условиях быстро изменяющегося финансового ландшафта различные исследователи отмечают, что завышенные прогнозы и ожидания, которые явились результатом агрессивных стратегий роста, привели многие крупнейшие транснациональные компании к существенным финансовым проблемам еще до кризиса. Отчасти это связано и с тем, что, столкнувшись с ограниченными возможностями роста, менеджеры таких компаний в ряде случаев «играли со стоимостью». Намного проще наращивать долг, осуществлять различные виды слияний и поглощений за счет долга, чем проводить реальную оптимизацию бизнес-процессов, отрезая «излишки жира» внутри самой организачии.

Незадолго до начала значительных кризисных трансформачий многие международные компании ставили во главу угла механизмы корпоративного управления, которые, как предполагалось, дадут возможность минимизировать реализачию нецелевых и во многом разрушительных для компаний решений. Однако стоит отметить, что во многих крупных известных компаниях, испытывающих значительные проблемы сейчас, такље были внедреньл данные механизмыл.

Одним из наших предположений является то, что значимым рычагом, который может снижать неэффективность систем корпоративного управления является система вознаграждения. Так, на панельной выборке удалось установить, что в определенной степени вознаграждение топ-менеджеров и совета директоров крупных российских компаний действительно позволяет опосредованно, через механизм принятия решений, влиять на ожидания рынка, что в свою очередь отражается на рыночной стоимости компании в той степени, в какой это возможно. Соответственно посредством выстраивания системы обоснованного вознаграждения возможно частично элиминировать конфликт интересов между менеджерами и акционерами, а значит, и снизить риски инвесторов.

На базе данного и ряда других исследований возможно проведение ряда дополнительных исследований для иелей оптимизации механизмов корпоративного управления. Так, с одной стороны, наблюдается положительное влияние вознаграждения топ-менеджмента и совета директоров через механизм принятия стратегических, управленческих и финансовых решений. С другой - возникают противоречия относительно компонентов вознаграждения, так как раскрываемая информация ничего не привносит в стоимость компании. Очевидно, что в уставном капитале существует определенная оптимальная доля ключевых лии компании, которая обезопасит компанию от столь критической с точки зрения разрушения финансового благополучия «игры со стоимостью». Для дальнейших исследований важно расширить диапазон и разнообразить интегральные рейтинги корпоративного управления крупных российских компаний.

JEL: G32. G34, G35, G38, G39, M51, M52

Ключевые слова: ограниченные возможности роста, возможности роста, оптимизация бизнес-процессов, корпоративное управление, финансовые затруднения

\footnotetext{
${ }^{35}$ Аспирант кафедры общего и стратегического менеджмента, преподаватель кафедры экономики и финансов фирмы, и.о. зам. зав. Лабораторией корпоративных финансов ГУ-ВШЭ.

36 Выпускница кафедры экономики и финансов фирмы, стажер Лаборатории корпоративных финансов ГУВШЭ.
}

Выпуск \#4(8), 2008

() Электронный журнал Корпоративные Финансы, 2008 
система корпоративного управления, система вознаграждения, вознаграждение топменеджеров, совет директоров, система обоснованного вознаграждения, интегральные рейтинги корпоративного управления, акционеры, опционы, структура собственности, рыночная капитализация, прочесс принятие решений, раскрытие информации.

\section{Исследование взаимосвязи стоимости и вознаграждения топ-менеджмента и совета директоров крупных российских компаний}

В последнее время в условиях быстро изменяющегося финансового ландшафта резко возрастает актуальность наличия механизмов, способствующих снижению рисков акционеров компании. Специалисты и эксперты все чаще отмечают, что завышенные прогнозы и ожидания, которые явились результатом агрессивных стратегий роста, привели многие крупнейшие транснациональные компании к повышению риска и значительной потере доходности акционеров компании. Отчасти это связано и с тем, что менеджеры транснациональных компаний в ряде случаев «играли со стоимостью», что привело к снижению сбалансированных резервов безопасности таких компаний, а, следовательно, в ряде случаев - и к существенным финансовым проблемам еще до кризиса (так случилось с гигантами автопромышленности США и Европы). В период кризиса, соответственно, данные проблемы значительно обострились. В создавшихся непростых условиях акционерам нужны понятные и действенные механизмы, которые могли бы помочь им снизить их риски таким образом, чтобы менеджеры перестали «играть со стоимостью».

Незадолго до начала значительных кризисных трансформаций многие международные компании ставили во главу угла механизмы корпоративного управления, которые, как предполагалось, дадут возможность минимизировать реализацию нецелевых и во многом разрушительных для компаний решений. Разделение собственно процесса управления и процесса владения компанией было призвано увеличить эффективность деятельности компании, а использование механизма советов директоров и внедрение управления стоимостью компании направлено на снижение конфликта целей между менеджерами и собственниками. Однако стоит отметить, что и в компании Enron и в других весьма известных компаниях также были внедрены данные механизмы. При этом были ли реализованы в действительности заявленные цели? Ответ на данный риторический вопрос можно получить сейчас: далеко не все компании, столь значимые для мировой экономики, смогли извлечь из прошлого чужого опыта стоящий урок.

Собственно неэффективность выстраиваемых систем корпоративного управления компаний развитых рынков не является главной причиной отсутствия запаса прочности крупных компаний, но она одна из основных. Знаменитый финансист Уоррен Баффетт в свое время произвел революцию в корпоративном управлении. Скупая наиболее перспективные открытые компании, он фактически трансформировал их в закрытые, тем самым максимально упрощая систему корпоративного управления.

«Не планируешь владеть компанией всю жизнь - не думай владеть ею и три минуты», - так говорил У. Баффетт. Собственник, чьи интересы напрямую связаны с долгосрочным благополучием компании, никогда не подвигнет ее на реализацию агрессивной стратегии роста, базирующейся на создании дутой отчетности.

Можно согласиться также и с тем, что внедрение сложнейших математических прогнозирующих моделей оценки роста, а также сложных схем корпоративного управления не избавит компанию от необходимости работать в стремительно изменяющейся реальности. Корпоративное управление, как система, призванная для реализации долгосрочных целей, на практике часто либо не содержит в себе элементов обоснованного вознаграждения топ-менеджмента, либо содержит в себе элементы вознаграждения для реализации краткосрочных целей. Это, в свою очередь, заставляет менеджеров «играть со стоимостью». Именно поэтому то вознаграждение ключевых лиц компании, которое смогло бы привести ее к долгосрочному росту стоимости, и является в действительности одним из 
тех механизмом, который смог бы обеспечить снижение рисков акционеров.

Так, исследователи пытаются рассматривать вознаграждение в зависимости от рыночной стоимости собственного капитала, а некоторые компании на этой волне выстраивают систему вознаграждения топ-менеджмента и совета директоров. При этом совершенно очевидны механизмы и во многом спекулятивные инструменты, которые по результатам года приведут к повышению рыночной стоимости компании, в том числе и просто на бумаге. В исследовании

Э. Байбуриной и И. Ивашковской было показано, что на шестилетней панельной выборке российских компаний их стоимость снижается за счет капитализации собственного капитала и одновременно с этим в большей степени растет за счет капитализации долгосрочного долга [Байбурина, Ивашковская, 2007].

Важно отметить, что есть исследователи, которые рассматривают вознаграждение в зависимости от стоимости компании, и при этом при расчете этой стоимости используют капитализацию совокупных активов, в том числе и долгосрочного долга. Соответственно, исследуя зависимость вознаграждения от стоимости совокупных активов, к примеру, на выборке российских компаний, мы получим, что чем больше менеджеры набрали долга за период, тем больше должно быть вознаграждение данных менеджеров. Исследование механизма повышения эффективности компании в такой взаимосвязи, на наш взгляд, в некоторых случаях приводит к «игре со стоимостью».

Рост крупных компаний за счет долга, а не за счет внутренней эффективности и внутренних возможностей, приводит к тому, что в них начинают развиваться и в крайней форме паразитировать так называемые болезни роста. Зачем развиваться и проводить эффективную оптимизацию бизнес-процессов, когда можно просто взять в долг, причем сумму не оптимальную, а непропорционально большую, чем реально требуется на те или иные стратегические цели, увеличивая таким образом стоимость компании за счет капитализации долгосрочного долга. При этом рост такой стоимости в краткосрочном периоде, тем не менее может обеспечиваться и за счет капитализации собственного капитала, так как инвесторы, видя на рынке положительный сигнал, начинают играть на повышение котировок акций: если компания берет в долг, значит, она может его обслуживать. Что будет с этой компанией через несколько лет, возможно, уже и не будет волновать ни топ-менеджмент, ни совет директоров, которые поменяют место работы; а если и не сделают этого, то, возможно, будут реструктуризировать долг или возьмут новый, проведут слияние и наконец обратятся за помощью к государству. И в том и в другом случае «раздувание пузыря» неизбежно. Именно поэтому, как бы ни хотелось исследовать зависимость вознаграждения топ-менеджмента по уже заявленным трудовым условиям от результатов деятельности, в данном случае будет происходить подмена понятий.

Условия вознаграждения топ-менеджмента и совета директоров известны последним до момента принятия решения. Таким образом, принимаемые решения с учетом данного знания и влияют уже в свою очередь на рыночную стоимость компании в той степени, в какой это возможно. При этом, бесспорно то, что принимаемые решения топ менеджментом - это один из ключевых факторов влияющий на рыночную стоимость компании, но при этом, отметим, не единственный. Бессмысленно привязывать вознаграждение топ-менеджмента в зависимости от рыночной капитализации на насыщенном рынке в краткосрочном периоде и исследовать это вознаграждение именно в этом ключе: это вынудит менеджмент «играть со стоимостью». Соответственно, для того чтобы вознаграждение топ-менеджмента не вынуждало его «играть со стоимостью», данный тип вознаграждения должен быть сформирован в большей степени как «гигиенический» фактор, нежели как «мотиватор», а быть при этом и гигиеническим фактором, и мотиватором. [Herzberg et al.,1959, 1993]. Вполне возможно, что мотиваторами в данных процессах может стать нефинансовая мотивация, что позволит предотвратить «игру со стоимостью». То есть вознаграждение топ-менеджмента должно опосредованно, через механизм принятия решений, в определенной степени влиять на рыночную капитализацию 
собственного капитала компании в долгосрочном периоде; прямое же влияние, как правило, может относиться лишь к краткосрочным спекулятивным механизмам.

Соответственно вознаграждение опосредованно, через механизм принятия решений топ-менеджментом и советом директоров, влияет на ожидания рынка, что в свою очередь отражается на рыночной стоимости компании в той степени, в какой это возможно. Кроме того, исследование зависимости вознаграждения от рыночной стоимости компании возможно лишь в том случае, если само вознаграждение в действительности полностью привязано к рыночной стоимости. Что, к примеру, для российских компаний скорее исключение, чем правило. Возникает и еще один негативный эффект: ожидания рынка, которые в итоге формируют рыночную стоимость, часто подвержены различным иррациональным эффектам, поведенческим, стадным и спекулятивным. «Рынок всегда прав, равно как рынок всегда не прав». Именно поэтому вознаграждение не должно быть полностью привязано к краткосрочным приростам рыночной стоимости компании. Реализация подобных мотивирующих программ является, по меньшей мере, неэффективной и часто губительной, на наш взгляд, для компании. И, наконец, во многих случаях в системе корпоративного управления система вознаграждения либо вообще отсутствует, а может существовать отдельно от системы корпоративного управления, либо присутствует в своих малоэффективных элементах.

Соответственно, одним из наших предположений является то, что значимым фактором, который может и должен приводить топ-менеджмент и совет директоров компании к реализации долгосрочных целей компании, является система вознаграждения. Данная система в реальности может быть как частью системы корпоративного управления, так и существовать отдельно от нее; хотя теоретически, естественно, система вознаграждения должна быть подсистемой корпоративного управления. Соответственно, соотношение системы вознаграждения с системой корпоративного управления во многих случаях является спорным.

Сама по себе система вознаграждения (на примере развивающихся рынков) представляет собой «черный ящик». Стоит отметить, что в этот «черный ящик» входит и вся нефинансовая мотивация, как то јob enrichment, job enlargement, корпоративная культура и т.д. Недостаток открытой информации и особая сложность ее интерпретации в данном случае приводит нас, как исследователей, к тому, что все внутренние процессы мы выносим за рамки рассмотрения данной статьи и более детально рассмотрим это в новых исследованиях.

В рамках данного исследования мы фокусируемся на входных параметрах системы в виде вознаграждения, и на выходе - результате. Именно эту взаимосвязь мы и постараемся исследовать на примере панельной выборки крупных российских компаний. Наше основное предположение связано с тем, что в реальности вознаграждение топ-менеджмента и совета директоров в среднесрочной перспективе (на данный момент мы можем получить только такую выборку по российскому рынку) должно в определенной степени через механизм принятия решений приводить к росту стоимости открытых крупных российских компаний. Соответственно, важно, насколько это возможно, выяснить, в какой степени вознаграждение топ-менеджмента и совета директоров приводит к росту стоимости. Исследование обратной взаимосвязи вознаграждения и стоимости компании выносится за грани нашей статьи по уже упомянутым причинам. В нашем исследовании мы рассмотрим также различные элементы корпоративного управления, которые могли бы привести крупные российские компании к росту стоимости.

\section{Подходы к оценке качества корпоративного управления и результатов деятельности компании}

На практике система вознаграждения может быть как частью системы корпоративного управления, так и существовать отдельно от нее; теоретически, естественно, система 
вознаграждения должна быть подсистемой корпоративного управления. Сама по себе эффективность и прозрачность системы корпоративного управления, финансовой архитектуры компании в достижении улучшения результатов деятельности компании часто определяется качеством корпоративного управления.

В последнее время растет количество работ, посвященных именно исследованию взаимосвязи качества корпоративного управления и результатов деятельности компании, а в частности - взаимосвязи качества корпоративного управления и стоимости, как результата деятельности компании. Тем не менее, несмотря на столь значительный интерес к данной взаимосвязи, единые трактовки понятий, как самого качества корпоративного управления, так и результатов деятельности компании вкупе со стоимостью отсутствуют.

В то же время растет число работ, целью которых является выявление взаимосвязи между вознаграждением топ-менеджмента и совета директоров и результатами деятельности компании. Хотя вознаграждение топ-менеджмента и совета директоров в теории представляет собой подсистему корпоративного управления с учетом нефинансовой мотивации и механизм без учета последней, часто оно используется и рассматривается отдельно от прочих подсистем и механизмов корпоративного управления.

На данный момент не существует единых критериев ни для определения качества корпоративного управления, ни для выявления результатов деятельности компании. Поэтому мы рассмотрим различные подходы к оценке качества корпоративного управления.

Корпоративное управление возникло в середине XVI века вместе с разделением между собственностью и управлением, и поэтому оно теснейшим образом связано с проблемой «принципал-агент» [Грачева, Карапетян, 2006]. Основная задача корпоративного управления заключается в устранении конфликта между принципалом - в лице различных собственников капитала компании — и агентом в лице топ-менеджеров компании и совета директоров, а также в минимизации агентских издержек. Таким образом, корпоративное управление представляет собой систему механизмов, «направленную на оптимизацию структуры корпоративных агентских отношений с целью обеспечения справедливого баланса интересов различных владельцев капитала (доминирующих и миноритарных акционеров, кредиторов), реализации эффективного инвестиционного процесса в компании и роста ее стоимости» [Родионов, Старюк, 2008].

При этом наиболее важными являются показатели, характеризующие деятельность советов директоров и топ-менеджмента. Вследствие отсутствия единого подхода к оценке качества работы советов директоров и топ-менеджмента таких показателей существует достаточно много. Соответственно, проводятся и разнообразные исследования взаимосвязи качества работы советов директоров и топ-менеджмента и результатов деятельности компании.

Так или иначе, но все имеющиеся исследования данной взаимосвязи можно поделить на несколько групп - в зависимости от подходов к оценке качества корпоративного управления, механизма вознаграждения и подходов к оценке результатов деятельности компании.

\section{Первая группа исследований взаимосвязи дискретных показателей качества корпоративного управления и результатов деятельности компании}

К первой группе исследований можно отнести те, в которых для выражения качества работы советов директоров рассматривается один из следующих признаков: частота проведения заседаний совета директоров, разделение позиций президента компании и председателя совета директоров, количество независимых директоров, доля независимых директоров. Для оценки результатов деятельности в данных работах используются подходы, основанные на бухгалтерских и рыночных показателях.

В рамках подхода, основанного на бухгалтерских показателях, рассматриваются следующие proxy-переменные: доходность собственного капитала $R O E$, доходность 
совокупных активов $R O A$, рентабельность продаж $R O S$; а в рамках подхода, основанного на рыночных показателях, - отношение скорректированной стоимости чистых активов к балансовой стоимости совокупных активов Tobin's $Q$, рыночный мультипликатор балансовой стоимости акционерного капитала market-to-book ratio и рыночный мультипликатор на основе продаж market-to-sales ratio.

Результаты данных исследований, как верно подмечают И.Ивашковская, А.Ращупкин и

Я. Осипов, неоднозначны. В большинстве исследований, проведенных в разных странах - Австралии, Сингапуре, Великобритании, США, - не обнаруживается статистически значимой взаимосвязи качества корпоративного управления, выраженного через долю независимых директоров с результатами деятельности компании [Ferris etc., 2002; Hermalin and Weisbach, 1988; Mehran, 1995; Lawrence \& Stapledon, 1997]. Так, Дж. Лоуренс и Дж. Степлдон не обнаружили взаимосвязи между долей независимых директоров и различными рыночными и бухгалтерскими показателями, С. Феррис и П. Стефен,- между долей независимых директоров и market-to-book ratio, а Б. Хермалин и М. Вайсбах- между долей независимых директоров и Tobin's $Q$. Также не обнаруживается взаимосвязь качества корпоративного управления, выраженного через количество независимых директоров, с рыночными и бухгалтерскими показателями [Leblanc, Gillies, 2005; Smith, Amoako-Adu].

В то же время есть ряд исследований, которые обнаруживают положительную [Vance, 1978; Rosenstein and Wyatt, 1990] и даже отрицательную [Yermack, 1996; Barnhart and Rosenstein, 1998; Agrawal and Knoeber, 1996] взаимосвязь качества корпоративного управления, выраженного либо через долю независимых директоров, либо через количество независимых директоров с рыночными и бухгалтерскими показателями.

Так, С. Розенштайн и Дж. Вайт показали, что цена акции в среднем вырастает на 0,2\% при включении в состав совета директоров еще одного независимого директора. Напротив, Д. Йермарк, а вслед за ним С. Барнхарт и С. Розенштайн пришли к выводу об отрицательной взаимосвязи качества корпоративного управления, выраженного через долю независимых директоров, с результатами деятельности компании, выраженными через показатель Tobin's $Q$. А. Агравал и С. Кнебер подтвердили данную взаимосвязь, но в более поздних работах: дополнив модель показателями государственного влияния, они заключили, что данная взаимосвязь ослабевает.

Наряду с вышеупомянутыми исследованиями существует также ряд работ, которые в качестве взаимосвязи доли независимых директоров с результатами деятельности компании рассматривают оптимальную структуру состава совета директоров. Так, С .Бхагат и Б. Блэк установили, что для более эффективной деятельности компании совет директоров, в среднем состоящий из 11 человек, должен наполовину состоять из независимых директоров [Bhagat and Black,1999].

\section{Вторая группа исследований взаимосвязи интегральных показателей качества корпоративного управления и результатов деятельности компании}

Во вторую группу исследований можно включить работы, в которых для обозначения качества деятельности советов директоров и топ-менеджеров рассматривается интегральный показатель - рейтинг корпоративного управления или самостоятельно разработанная исследователями система показателей корпоративного управления; а для оценки результатов деятельности компании применяются подходы на основе бухгалтерских, рыночных и стоимостных показателей. При этом в рамках стоимостного подхода используются следующие переменные: рыночная капитализация акционерного капитали компании $M C$, экономическая добавленная стоимость $E V A$ и рыночная добавленная стоимость $M V A$.

Этой группе исследований стоит уделить особое внимание. Во-первых, потому, что в работах данного типа установлена зависимость между рыночной стоимостью компании и качеством корпоративного управления. Во-вторых, потому, что, в отличие от первой группы исследований, затронувших в большинстве своем только развитые страны и совсем не 
затронувших Россию, ряд работ из второй группы исследований имел своей целью установление зависимости между рыночной стоимостью компании и качеством корпоративного управления (на примере компаний из развивающихся стран, в частности, российских компаний).

Одним из первых исследований, направленных на изучение зависимости между рыночной стоимостью российской компании и качеством корпоративного управления, было исследование Б. Блэка 2001 года [Black, 2001]. В данной работе Б. Блэк изучал взаимосвязь между рейтингом корпоративного управления и отношением рыночной капитализации компании к потенциальной оценке рыночной капитализации. Рейтинг корпоративного управления представлен рейтингом Brunswick Warburg, отражает существующие и потенциальные риски компании, связанные с корпоративным управлением, и потому включает в себя следующие компоненты:

- прозрачность и раскрытие информации,

- размывание путем выпуска акций,

- размывание посредством слияний и реструктуризации,

- выкачивание активов и трансфертное ценообразование,

- банкротство,

- ограничения прав собственности иностранцев,

- отношение руководства к акционерам, регистратор, аффилированный с компанией.

Рейтинг присваивается российским компаниям от 0 до 72 баллов, показывая тем самым, что, чем хуже качество корпоративного управления в компании, тем больше у нее значение рейтинга.

Отношение рыночной капитализации компании к потенциальной оценке рыночной капитализации построено по методике ОАО «Тройки-Диалог» «Value Ratio». Рейтинг присваивается по шкале от 5 до 15 баллов и включает в себя такие компоненты, как:

- структура контроля и надзора,

- отношения руководства и инвесторов,

- осуществление корпоративного руководства,

- раскрытие информации и прозрачность,

- финансовая дисциплина,

- структура собственности.

В итоге автор исследования пришел к следующему выводу: рост рейтинга корпоративного управления от наихудшей позиции - 51 - до наилучшей - 7 - может увеличить рыночную стоимость российской компании в 673 раза.

В следующем исследовании, проведенном уже несколько лет спустя, Б. Блэк, И. Лав, А. Рачинский были уже менее оптимистичны в отношении данной взаимосвязи и высказали предположение, что рост рейтинга корпоративного управления от наихудшей позиции до наилучшей может привести к росту рыночной стоимости российской компании на $81 \%$ [Black, Love, Rachinsky, 2006]. Помимо выявления известной взаимосвязи, в данной работе авторами также был произведен сопоставительный анализ влияния разных рейтингов корпоративного управления на рыночные показатель Tobin's $Q$.

Было установлено, что наибольшим влиянием на переменную логарифма Tobin's $Q$ обладает рейтинг прозрачности и раскрытия информации $S \& P^{37}$, который включает четыре компонента: раскрытие финансовой информации, раскрытие операционной информации, раскрытие информации о собственности и раскрытие информации о совете директоров и топ-менеджменте. Для этого рейтинга авторы получили положительно значимые коэффициенты как в сквозной регрессии, так и в регрессии с фиксированными эффектами. Также авторы рассмотрели рейтинг ICLG, он присваивается по 100-балльной шкале и включает в себя следующие компоненты:

\footnotetext{
${ }^{37}$ Рейтинг присваивает по шкале от 0 до 89.

Выпуск \#4(8), 2008 С Электронный журнал Корпоративные Финансы, 2008
} 
- раскрытие информации,

- структура собственности,

- структура совета директоров и руководства компании,

- права акционеров,

- риск потери собственности,

- история корпоративного управления.

Для рейтингов Brunswick, «Value Ratio», и ICLG авторы также получили положительно значимые коэффициенты, но только в регрессии с фиксированными эффектами. А для рейтинга «РИД-Эксперт РА» авторы получили положительно значимые коэффициенты в сквозной регрессии, но отрицательные незначимые - в регрессии с фиксированными эффектами. Что касается рейтинга корпоративного управления $S \& P$ Governance $^{38}$, то в обеих регрессиях он оказался незначимым.

Почти к такому же выводу пришли российские исследователи И. Родионов и П. Старюк. Построенная ими регрессия (на основе данных по 40 крупнейшим публичным российским компаниям) показала высокую статистическую значимость корпоративного управления, как самостоятельного фактора формирования стоимости российских компаний [Родионов, Старюк, 2008]. В своей работе авторы применили стоимостной подход к оценке результатов деятельности компании, и в рамках стоимостного подхода использовали показатель рыночной капитализации. В роли переменной, описывающей качество корпоративного управления, ими был использован рейтинг корпоративного управления $C O R E^{39}$, агрегирующий деятельность совета директоров и топ-менеджмента, системы вознаграждения, раскрытие информации, структуру акционерного капитала, структуру корпоративного управления, декларируемые права акционеров и корпоративное окружение. При этом авторы пришли к выводу, что за счет улучшения качества корпоративного управления можно достичь $90 \%$-ного роста стоимости рыночной капитализации российской компании.

Вышеупомянутый А. Рачинский тоже исследовал взаимосвязь между рыночной капитализацией российской компании и рейтингами корпоративного управления рейтингом CORE и рейтингом Brunswick. В свою модель он также включил фундаментальные факторы создания стоимости и сделал на них особый акцент. А. Рачинский заключил, что рейтинги и фундаментальные финансовые переменные являются отражением различных сторон деятельности компании и имеют разное влияние на ее стоимость [Рачинский, 2003]. Так же, как и во всех предыдущих исследованиях, А. Рачинский установил, что улучшение качества корпоративного управления будет способствовать росту стоимости российской компании, причем рост рейтинга на 15 пунктов (переход компании из разряда худших в середняки) вызовет увеличение стоимости компании на $37 \%$.

Что касается взаимосвязи такого стоимостного показателя оценки результатов деятельности компании, как $E V A$, и рейтинга корпоративного управления, то результаты работ, выполненных на примере канадских и американских компаний, - одни и те же. Так, исследователи Ф. Аджаоди, Д. Зегхал, С. Андалееб, подтвердили, что между EVA и рейтингом корпоративного управления $C N N$ существует положительная статистически значимая зависимость [Adjaodi, Zeghal, Andaleeb, 2007].

В отношении российских компаний такого сказать нельзя. Так, в своем исследовании взаимосвязи $E V A$ и рейтинга корпоративного управления - рейтинга прозрачности и раскрытия информации $S \& P$ - авторы работы И. Ивашковская, М. Пономарева и А. Сеттлз пришли к выводу о наличии положительной статистически значимой связи между двумя данными показателями [Ивашковская, Пономарева, Сеттлз, 2007].

В следующем исследовании выводы были кардинально противоположными: была

\footnotetext{
${ }^{38}$ Рейтинг присваивается по 10-балльной шкале.

${ }^{39}$ Рейтинг присваивается по 100-балльной шкале.

Выпуск \#4(8), 2008

() Электронный журнал Корпоративные Финансы, 2008
} 
обнаружена отрицательная статистически значимая зависимость между $E V A$ и рейтингом корпоративного управления - «РИД-Эксперт РА» [Ивашковская, Осипов, Ращупкин, 2008].

\section{Третья группа исследований взаимосвязи интегральных и дискретных показателей качества корпоративного управления и результатов деятельности компании}

К третьей группе исследований можно отнести исследования второй группы, но с некоторым дополнением: помимо исследования взаимосвязи качества корпоративного управления, представленного в виде некого интегрального показателя - рейтинга корпоративного управления, и различных результатов деятельности компании также имеет место исследование взаимосвязи каждого отдельно взятого элемента, входящего в состав рейтинга корпоративного управления, и различными результатами деятельности компании. При этом, в отличие от второй группы исследований, в рамках данной группы работ для оценки результатов деятельности компании применяются подходы на основе бухгалтерских, рыночных и стоимостных показателей.

Так, в результате исследования корейских компаний Б. Блэк, Э. Джанг, В. Кимпришли к выводу о положительной статистически значимой взаимосвязи между рейтингом корпоративного управления KCGI (рейтинг разработан по авторской методике) и показателем Tobin's $Q$ [Black, Jang и Kim, 2005]. Рейтинг KCGI присваивается по 100балльной шкале на основе коэффициентов, полученных в сквозной регрессии по следующим компонентам:

- права акционеров,

- структура совета директоров,

- функции членов совета директоров и членов комитета по аудиту,

- структура собственности,

- раскрытие информации.

Исследователи особо отметили тот факт, что изменение позиции в рейтинге от наихудшей к наилучшей может привести к росту Tobin's $Q$ на $0,47 \%$ и к росту рыночной капитализации компании на $160 \%$. Еще один очень важный вывод, к которому пришли авторы, заключается в том, что у корейских фирм, совет директоров которых наполовину состоит из независимых членов, показатель Tobin's $Q$ на $0,13 \%$ больше, а рыночная капитализация - на 40\% больше. Таким образом, авторы заключили, что на развивающихся рынках рост доли независимых директоров ведет к росту рыночной капитализации компании.

Существенное количество выводов в своей работе сделали Л. Браун и М. Кейлор. Вопервых, они обнаружили положительную взаимосвязь между сконструированным ими рейтингом Gov-Score и показателем Tobin's $Q$, а также между рейтингом Gov-Score и ROE. Рейтинг Gov-Score присваивается по шкале от 0 до 51 балла и включает в себя таки компоненты, как:

- информация о комитете по аудиту,

- структура совета директоров,

- устав компании,

- образование членов совета директоров,

- вознаграждение членов совета директоров и топ-менеджмента компании,

- структура собственности,

- передовая практика управления,

- положение об объединении.

Во-вторых, они пришли к выводу, что такая составляющая рейтинга Gov-Score, как вознаграждение топ-менеджеров и совета директоров, оказывает самое сильное положительное влияние на показатели Tobin's $Q$ и $R O E$. В-третьих, авторами работы была доказана положительная взаимосвязь между долей независимых директоров и показателями 
Tobin's $Q$ и $R O E$ [Brown, Caylor, 2004].

\section{Четвертая группа исследований взаимосвязи между вознаграждением топ- менеджмента и совета директоров и результатами деятельности компании}

Четвертая группа исследований представляет собой особый интерес. К ней можно отнести работы, направленные на изучение взаимосвязи между вознаграждением топменеджмента и совета директоров и результатами деятельности компании, представленными бухгалтерскими, рыночными и стоимостными показателями. Несмотря на то, что в исследовании предыдущего типа вознаграждение топ-менеджмента и совета директоров фигурировало в качестве механизма корпоративного управления [Brown, Caylor, 2004] и ему было уделено особое внимание, это большая редкость. Поэтому, как уже было сказано выше, четвертый пласт работ стоит несколько обособленно от исследований взаимосвязи между качеством корпоративного управления и результатами деятельности компании; хотя, на наш взгляд, он имеет самое непосредственное отношение к исследованию специфики данной системы корпоративного управления.

Как уже было отмечено выше, до недавнего кризисного времени большинство западных исследований имеет своей целью выявление зависимости не стоимости компании от вознаграждения топ-менеджмента и совета директоров, а, наоборот, вознаграждение топменеджмента и совета директоров зависит от стоимости компании.

Обратимся к таким исследованиям. Стоит отметить, что в большинстве своем авторы этих работ заявляют о положительном статистически значимом влиянии стоимостной оценки результатов деятельности компании, представленной в виде показателей $E V A$ или $M V A$, на вознаграждение топ-менеджмента и совета директоров. Так, в своей работе А. Десэй, А.Фатеми и Дж. Катц обнаружили положительную статистически значимую зависимость вознаграждения топ-менеджмента и совета директоров от результатов деятельности компании, представленных в виде показателей $E V A$ и $M V A$ [Desay, Fatemi, Katz, 1999]. К такому же выводу пришли С. Баум, Л. Сарвер, Т. Стрикланд, добавив при этом, что показатель $M V A$ в большей степени оказывает влияние на вознаграждение топменеджмента и совета директоров, нежели $E V A$, и это влияние распространяется на каждый компонент вознаграждения [Baum, Sarver, Strickland, 2004]. Дж. Гриффит и М. Наджанд также подтвердили результаты своих коллег, указав на положительную статистически значимую зависимость вознаграждения топ-менеджмента и совета директоров от результатов деятельности компании, представленных в виде показателей MVA и Tobin's $Q$ [Griffith, Najand, 2006]. Однако выводы данных работ указывают исключительно на то, что если рассчитывать стоимость компании через показатель MVA, то по результатам работы за период (как правило, год), менеджеры должны получить большее вознаграждение. Однако совершенно очевидно, что те механизмы, которые расчетно будут увеличивать показатель MVA, и будут реализовываться менеджерами в виде «игре со стоимостью» с целью получения большего вознаграждения, что и приведет в краткосрочном годовом периоде к увеличению вознаграждения, а в долгосрочном периоде - к серьезным финансовым затруднениям.

Условия вознаграждения топ-менеджмента и совета директоров известны последним до момента принятия стратегических, управленческих и финансовых решений (рис.1). Именно принимаемые с учетом данного факта решения и влияют, уже в свою очередь, разумеется, в той степени, насколько это возможно на стоимость компании, которая может быть рассчитана как через показатели MVA, так и EVA, так и в особенности через показатель рыночной капитализации. 


\section{Рис. 1. Влияние вознаграждения топ-менеджмента через механизм принятия решений на стоимость компании}

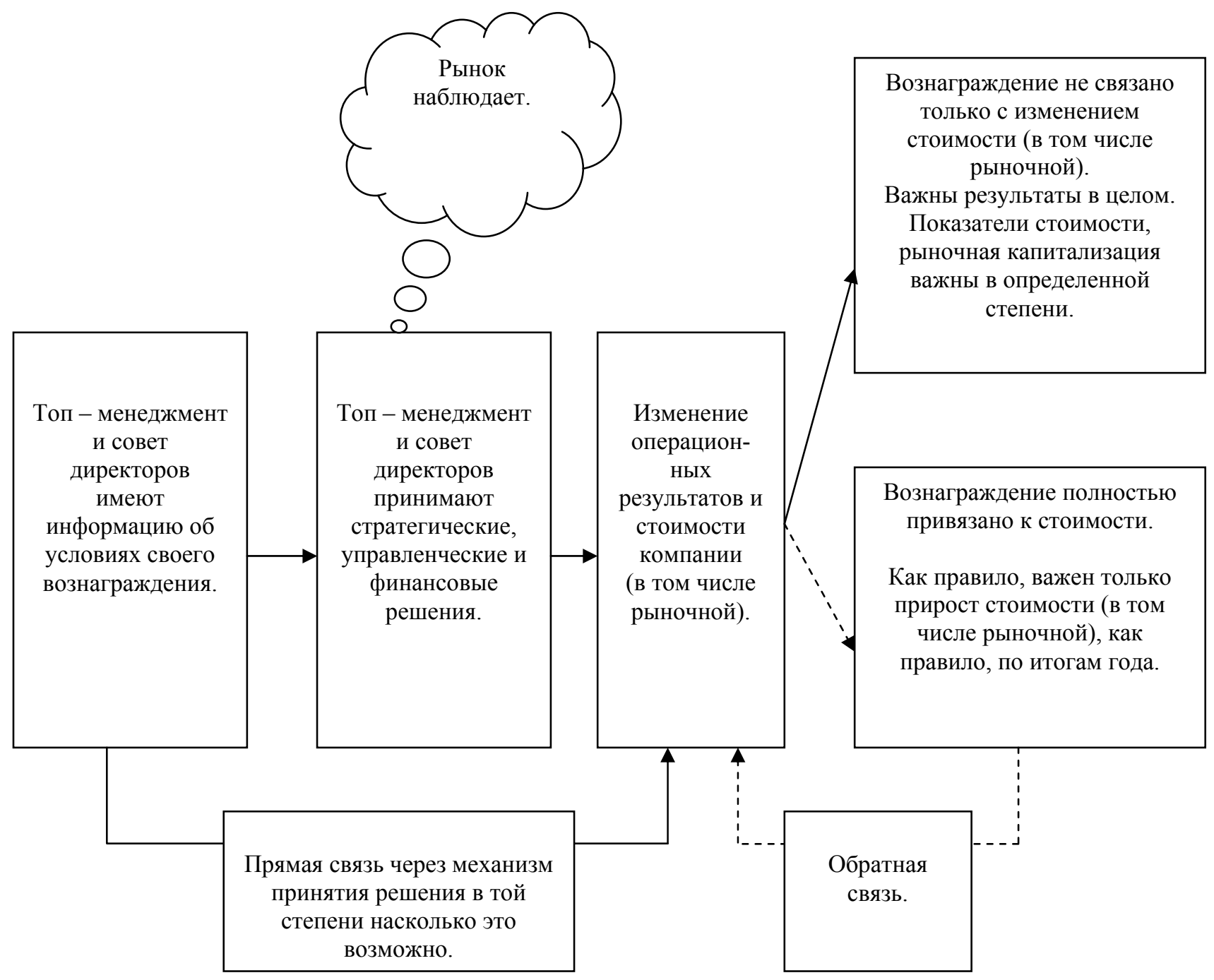

Определение вознаграждения топ-менеджмента в зависимости от стоимости компании, по сути, на насыщенном рынке и в краткосрочном периоде вынудит менеджмент «играть со стоимостью», так как вне зависимости от расчетной методики стоимости возможности быстрого качественного роста, как правило, по итогам года, очевидно, будут ограниченны. Так, например, еще задолго до нынешнего кризиса некоторые исследователи, используя такое определение вознаграждения, недоумевали, почему в 2001 году падение рыночной капитализации американских корпораций привело к 7\%-ному росту общего объема вознаграждений топ-менеджмента и совета директоров. Соответственно, теперь одна из задач исследователей в данной области заключается в совершенствовании системы корпоративного управления и качественном изучении систем вознаграждения.

Соответственно, в рамках четвертой группы появился ряд исследований, которые на наш взгляд, особо перспективен, - это исследования зависимости стоимостных и рыночных показателей результатов деятельности компании от вознаграждения топ-менеджмента и совета директоров и других показателей корпоративного управления через наблюдаемый рынком механизм принятия стратегических, управленческих и финансовых решений.

Таких работ не так много, но все же все они подтверждают положительную статистически значимую зависимость стоимостных показателей результатов деятельности 
компании от вознаграждения топ-менеджмента и совета директоров [Evans, Evans, 2003]. Так, М. Шайкхолеслами обнаружил положительную статистически значимую зависимость показателя $E V A$ от вознаграждения топ-менеджмента и совета директоров в виде заработной платы и бонусов. Также он обнаружил положительную, но статистически незначимую зависимость показателя EVA от вознаграждения топ-менеджмента и совета директоров в виде опционов на покупку акций, предположив при этом, что, возможно, опционы на покупку акций повлияют на будущие показатели $E V A$ [Sheikholeslami, 2001].

Хотя большинство западных исследователей пришли к такому же выводу относительно зависимости стоимостных показателей компании от вознаграждения топ-менеджмента и совета директоров в виде опционов на покупку акций (т.е. об отсутствии такой зависимости), некоторые авторы с этим не соглашаются [Murphy, 1998]. Так, Р. Массон, а вслед за ним и Дж. Абвод объявили о существовании положительной статистически значимой зависимости рыночной капитализации компании от вознаграждения топменеджмента и совета директоров в виде опционов на покупку акций [Masson, 1971; Abowd, 1990]. В свою очередь Х.Мейран тоже обнаружил положительную статистически значимую зависимость, но уже показателей Tobin's $Q$ и ROA от вознаграждения топ-менеджмента и совета директоров в виде опционов на покупку акций.

Помимо этого Х.Мейран также сделал вывод о наличии положительной статистически значимой зависимости показателей Tobin's $Q$ и $R O A$ от доли акций компании, находящейся в руках у топ-менеджеров и совета директоров [Mehran, 1995]. К такому же выводу относительно наличия положительной статистически значимой зависимости результатов деятельности компании от доли ее акций, находящейся в руках у топ-менеджеров и совета директоров, пришли Р. Ламберт и Д. Ларкер (1987); Д. Даливал, Дж. Саламон и Е. Смит (1982), Р. Морк, А. Шлейфер и Р. Вишны обнаружили, что показатель Tobin's $Q$ увеличивается с ростом доли акций компании, находящейся в руках у топ-менеджеров и совета директоров, когда та находится в интервале от 0 до 5\% или превышает $25 \%$. Когда же доля акций компании у топ-менеджеров и совета директоров находится в интервале от 5 до 25\%, этот эффект обратный, но статистически незначимый [Morck, Shleifer,Vishny, 1988]. Дж. Макконнал и Х. Сервас заключили, что Tobin's $Q$ увеличивается с ростом доли акций компании, находящейся в руках у топ-менеджеров и совета директоров, когда та не превышает 40-50\% [McConnell, Servaes, 1990]. Дж. Эванс и Р. Эванс, в свою очередь, тоже сделали вывод о наличии положительной статистически значимой зависимости показателя $E V A P S$ ( $E V A$ на акцию) от доли акций компании, находящейся в руках у топ-менеджеров и совета директоров. Помимо этого они также обнаружили отрицательную статистически незначимую зависимость показателя $E V A P S$ от вознаграждения топ-менеджмента и совета директоров в виде заработной платы и бонусов [Evans, Evans, 2003].

\section{Анализ четырех взаимосвязей}

Все рассмотренные нами взаимосвязи подталкивают нас к следующим выводам.

Во-первых, результаты исследования как развитых стран, так и развивающихся, сходятся, как минимум, на том, что улучшение качества корпоративного управления и совершенствование системы вознаграждения ведет к росту стоимости компании.

Во-вторых, результаты исследований и тех и других стран также одинаково показывают положительную статистически значимую зависимость стоимости компании от качества корпоративного управления, представленного в виде интегрального показателя.

В-третьих, несмотря на то, что результаты исследований развитых стран противоречивы в отношении влияния доли независимых директоров как показателя качества корпоративного управления на результаты деятельности компании, в частности, представленные стоимостными показателями, результаты исследования развивающихся стран показали, что характер этого влияния носит положительный статистически значимый оттенок. 
В-четвертых, вопреки тому, что исследования взаимосвязи между вознаграждением топ-менеджеров и совета директоров и результатами деятельности компании стоят обособленно от исследований взаимосвязи между качеством корпоративного управления и результатами деятельности компании (мы выделяем данные исследования в отдельную, четвертую группу), результаты этих исследований свидетельствуют об одном и том же. Так, с одной стороны, они говорят о положительной статистически значимой зависимости вознаграждения топ-менеджмента и совета директоров от стоимостного показателя $E V A$ и от бухгалтерских показателей результатов деятельности компании. С другой стороны, они заявляют о наличии положительной статистически значимой зависимости стоимости компании, в частности представленной показателем рыночной капитализации, от вознаграждения топ-менеджмента и совета директоров.

В-пятых, несмотря на то, что большинство результатов исследований не показывает наличие статистически значимой зависимости результатов деятельности компании, в том числе представленных стоимостными показателями, от вознаграждения топ-менеджмента и совета директоров в виде опционов на покупку акций, большая часть из этих исследований утверждает, что характер этой зависимости носит положительный оттенок. А часть исследований (ранних исследований, когда опционы на покупку акций только начали появляться) говорит о положительном статистически значимом воздействии опционов на покупку акций на результаты деятельности компании, в том числе на ее стоимость.

И наконец, в-шестых, результаты исследований в отношении влияния доли акций компании, находящейся в руках у топ-менеджеров и совета директоров, на результаты деятельности компании, представленные стоимостными и рыночными показателями, весьма похожи. Они сходятся на том, что характер данного влияния носит положительный статистически значимый оттенок.

\section{Эмпирическое исследование зависимости рыночной капитализации крупных российских компаний от вознаграждения топ-менеджмента и совета директоров}

Цель нашего исследования заключается в анализе влияния вознаграждения топменеджмента и совета директоров на стоимость крупных открытых российских компаний.

Еще раз стоит отметить, что вознаграждение топ-менеджмента и совета директоров представляет собой механизм корпоративного управления. Первоочередной задачей данного механизма (о чем, как ни странно, говорят все исследователи зависимости результатов деятельности компании от вознаграждения топ-менеджеров и совета директоров) выступает решение проблемы «принципал - агент» и снижение агентских издержек (другими словами - сбалансированность интересов акционеров компании, топ-менеджеров и совета директоров).

В рамках данного исследования к совету директоров мы будем относить всех членов совета директоров, а всех членов правления — к топ-менеджерам.

Теперь мы можем перейти к описанию вознаграждения топ-менеджеров и совета директоров. Так, в рамках данного исследования под вознаграждением топ-менеджмента и совета директоров мы будем понимать денежное вознаграждение, включающее заработную плату, бонусы, премии, компенсацию расходов, вознаграждение и иные имущественные предоставления в денежном эквиваленте, а также вознаграждение в виде опционов на покупку акций. Что касается выплаты вознаграждения в виде опционов на покупку акций, то за рубежом это распространенная практика. В России же она только начинает набирать обороты.

На данной стадии исследования мы можем перейти к формированию гипотез.

В первой главе было сказано, что в большей части исследований сделан вывод о наличии положительной статистически значимой зависимости стоимости компании от вознаграждения топ-менеджмента и совета директоров.

Следуя логике, что первоочередной задачей вознаграждения топ-менеджмента и совета 
директоров является снижение посредством механизма мотивации агентских издержек, должное привести к росту стоимости компании, мы выдвигаем первую гипотезу:

H1: в определенной степени денежное вознаграждение топ-менеджмента и совета директоров влияет в среднесрочной перспективе через механизм принятия решений на рыночную капитализацию компании, и это влияние положительно и значимо.

Также особые выводы ранее мы сделали относительно вознаграждения топменеджмента и совета директоров в виде опционов на покупку акций. Так, в ходе большинства исследований установлена статистически не значимая, но положительная зависимость стоимости компании от вознаграждения топ-менеджмента и совета директоров в виде опционов на покупку акций, а ряд исследований даже подтвердил эту статистическую значимость. Чем же это можно объяснить? Это можно объяснить тем, что вознаграждение в виде опциона на покупку акций опять-таки через механизм мотивации способствует тому, что топ-менеджеры и совет директоров, преследуя личные цели, одновременно начинают действовать и в интересах акционеров, заключающихся в росте стоимости компании. Поэтому вторая гипотеза звучит следующим образом:

H2: вознаграждение топ-менеджмента и совета директоров в виде опџиона на покупку акций положстельно влияет на рыночную капитализацию компании.

Третья гипотеза, выдвигаемая нами, уже будет касаться не самого вознаграждения топменеджмента и совета директоров компании, а раскрытия информации по вознаграждению, в частности по денежному. При выдвижении данной гипотезы мы будем исходить из того, что раскрытие информации по компонентам денежного вознаграждения делает компанию более прозрачной и открытой для рынка. При этом рынок имеет возможности сравнить соотношение денежных компонентов в данной компании с соотношением денежных компонентов в других компаниях и сделать определенные выводы касательно деятельности компании, топ-менеджеров и совета директоров; после этого, основываясь на данных выводах, рынок может принять определенные решения. Таким образом, третья гипотеза гласит следующее:

H3: раскрытие информации по компонентам вознаграждения топ-менеджмента и совета директоров положительно влияет на рыночную капитализацию компании.

Мы отмечали выше, что влияние доли независимых директоров как показателя качества корпоративного управления на стоимость компании в развитых странах неоднозначно, но в развивающихся странах характер этого влияния носит положительный статистически значимый оттенок.

Прежде чем выдвигать гипотезу относительно доли независимых директоров, необходимо понять, кто же они такие - независимые директора.

Согласно отчету о результатах исследования «Роль независимых членов советов директоров в управлении российскими предприятиями», проведенного Ассоциацией независимых директоров, в России под термином «независимый директор» обычно понимают директора, отвечающего следующим основным критериям:

- он не находится в финансовой либо иной зависимости от акционера, владеющего более $25 \%$ голосующих акций;

- он не находится в финансовой либо иной зависимости от исполнительного руководства компании;

- он не находится в финансовой либо иной зависимости от крупных контрагентов компании;

- он не является представителем государства, даже если государство является миноритарным акционером;

- $\quad$ он не находится в финансовой либо иной зависимости от аудиторов, оценщиков либо консультантов компании;

- в своей деятельности он не преследует личные политические цели.

Основываясь на результатах традиционных исследований развивающихся стран, на самом понятии независимого директора и следуя традиционной логике, что присутствие
Выпуск \#4(8), 2008
() Электронный журнал Корпоративные Финансы, 2008 
независимых членов в составе совета директоров способствует сбалансированию интересов разных групп стейкхолдеров, в первую очередь миноритарных акционеров и доминирующих акционеров, а также принятию более эффективных решений, мы выдвигаем четвертую гипотезу:

H4: доля независимых директоров в составе совета директоров положительно влияет на рыночную капитализачию компании.

Наша пятая гипотеза будет касаться доли в уставном капитале компании, принадлежащей топ-менеджерам и совету директоров. Так, ранее мы пришли к выводу, что доля акций компании, находящаяся в руках у топ-менеджеров и совета директоров, положительно влияет на стоимость компании, и характер этого влияния носит статистически значимый оттенок.

Следуя такой же логике, что и другие исследователи, а именно, что инвестиции в компанию со стороны топ-менеджеров и совета директоров ведут к устранению разделения между собственником и управленцем, то есть к сокращению агентских издержек, мы выдвигаем пятую гипотезу:

H5: доля в уставном капитале компании, принадлежащая топ-менеджерам и совету директоров, положительно влияет на ее рыночную капитализацию.

Соответственно остается еще один существенный вопрос, заключающийся в выборе интегрального показателя качества корпоративного управления. Здесь мы последуем логике авторов - И. Ивашковской, А. Ращупкина, Я. Осипова [Ивашковская и др., 2008], которые последовательно отвергают два из трех на сегодняшний день присваиваемых и регулярно обновляемых рейтинга корпоративного управления российских компаний «Тройку-Диалог» (по причине закрытости информации) и S\&P (по причине маленького охвата - всего 18 компаний) - и тоже их отвергнем. Так, мы остановим свой выбор на рейтинге корпоративного управления «РИД-Эксперт РА», который явно и целенаправленно не рассматривает систему вознаграждения ключевых лиц компании, но зато учитывает другие аспекты и обладает достаточной широтой обхвата (на сегодняшний день это около 160 компаний). В основе методики рейтинга - сопоставление сложившейся в компании практики корпоративного управления с требованиями российского законодательства, рекомендациями Кодекса корпоративного управления, а также другими стандартами российской и международной передовой практики корпоративного управления. Практика корпоративного управления оценивается более чем по 100 критериям, агрегированным в следующих четырех ключевых компонентах, при этом система вознаграждения не выделена в отдельный компонент и не рассматривается отдельно:

- права акционеров (уровень соблюдения компаниями прав акционеров, касающихся права голоса и участия в управлении, получения доли материальных выгод, получения своевременной и качественной информации о деятельности общества);

- деятельность органов управления и контроля (состав и организация работы совета директоров, практика корпоративного управления с точки зрения деятельности исполнительных органов и органов контроля исследуемых компаний);

- раскрытие информации (уровень раскрытия финансовой и нефинансовой информации, оперативность ее предоставления и доступность для всех заинтересованных сторон);

- корпоративная социальная ответственность и учет интересов стейкхолдеров (соблюдение установленных законом прав и учет интересов «иных заинтересованных групп» (стейкхолдеров), развитие сотрудничества между компаниями и такими группами).

При этом рейтинг корпоративного управления «РИД-Эксперт РА» присваивается по шкале от 1 (низшая оценка) до 10 (высшая оценка).

Соответственно, последняя, шестая гипотеза, которую мы будем тестировать, связана с интегральным показателем качества корпоративного управления «РИД-Эксперт РА», 
который в явном и целенаправленном виде не рассматривает систему вознаграждения ключевых лиц компании. Ранее были сделаны выводы, что, интегральный показатель качества корпоративного управления оказывает положительное статистически значимое влияние на стоимость как компании из развитой страны, так и компании из развивающейся страны.

Следуя данным выводам, мы выдвигаем последнюю гипотезу:

Н6: интегральный показатель качества корпоративного управления положительно влияет на рыночную капитализацию компании.

На следующем этапе исследования мы можем перейти к описанию выбора показателей.

Уже, исходя из наших гипотез, можно заметить, что в качестве показателя результатов деятельности компании и показателя ее стоимости мы рассматриваем рыночную капитализацию акционерного капитала.

Наш выбор пал именно на рыночную капитализацию акционерного капитала по нескольким причинам.

Во-первых, поскольку центральным объектом нашего исследования выступает вознаграждение топ-менеджеров и совета директоров, смысл которого заключается в снижении агентских издержек и сбалансированности интересов собственников и акционеров, постольку наблюдаемым механизмом, позволяющим проследить собственникам, приводит ли данное вознаграждение к снижению агентских издержек и росту стоимости компании или нет, является рыночная капитализация акционерного капитала.

Во-вторых, нас интересует степень влияния вознаграждения топ-менеджмента и совета директоров на результаты деятельности компании, а не наоборот.

С одной стороны, уже была найдена положительная статистически значимая зависимость вознаграждения топ-менеджмента от показателей EVA, MVA, Tobin's $Q$. C другой стороны, большинство компаний привязывают некоторые компоненты вознаграждения к бухгалтерским показателям. Особо отметим и подчеркнем в данном случае, что целесообразен выбор показателя рыночной капитализации акционерного капитала, который должен быть одним из результатов деятельности, но при этом не должен ложиться в основу критерия вознаграждения топ-менеджмента и совета директоров [Reddy, Reddy, 2006].

К тому же против использования такого известного показателя стоимости, как $E V A$, есть еще один очень важный аргумент: весьма авторитетные исследования, проведенные компаниями McKinsey\&Co, KPMG, BCG, Merrill Lynch, Stern Stewart\&Co (создателями EVA $\left({ }^{\circledR}\right)$, позволяют сделать вывод, что показатель EVA не имеет тесной связи со стоимостью бизнеса [Ковалев, 2007)] и не интересен акционерам компании.

В-третьих, исследования российских рынков, положившие в основу результатов деятельности компании стоимость и, в частности, рыночную капитализацию, выявили положительную статистически значимую зависимость рыночной капитализации от интегрального показателя качества корпоративного управления, а исследования российских рынков, положившие в основу результатов деятельности компании показатель $E V A$, пришли к противоречащим результатам. Таким образом, мы останавливаем свой выбор на рыночной капитализации акционерного капитала.

Теперь мы можем перейти к описанию выборки и ее параметров.

Компании, попавшие в нашу выборку, должны были соответствовать следующим критериям:

- акции данных компаний должны котироваться на бирже РТС (данное условие необходимо для адекватной рыночной оценки капитализации компании);

- данные компании должны входить в Топ-300 журнала «Коммерсант-Первый рейтинг» № 1 от 14 января 2008 года (данное условие необходимо для ограничения понятия «крупнейшая компания»);

- данные компании должны раскрывать информацию о вознаграждении топ- 
менеджеров и совета директоров хотя бы в виде общей суммы;

- д данные компании должны иметь отчетность по IAS/GAAP в 2004, 2005, 2006 годах;

- данные компании должны иметь рейтинг «РИД-Эксперт РА» в 2004, 2005, 2006 годах.

В нашу выборку попали 26 крупнейших российских компаний из различных отраслей: нефтегазовой, химической, пищевой, черной металлургии, цветной металлургии, машиностроения, энергетики, телекоммуникаций, транспорта. Данные по компаниям носят панельный характер, так как собирались по трем годам - 2004, 2005 и 2006 году. Общее число наблюдений в нашей выборке составило 78.

В качестве зависимой переменной, как уже было сказано выше, мы взяли:

$M C$ - рыночную капитализацию акционерного капитала компании (USD).

B качестве независимых переменных мы рассматривали следующие показатели:

Assets - активы компании, фундаментальный фактор роста стоимости (USD);

$T R$ - выручку компании, фундаментальный фактор роста стоимости (USD);

NI - чистую прибыль компании, фундаментальный фактор роста стоимости (USD); (USD);

Compensation - денежное вознаграждение топ-менеджмента и совета директоров

Inddirect - долю независимых директоров в составе совета директоров;

Share - долю в уставном капитале компании, принадлежащую топ-менеджменту и совету директоров;

Index - значение рейтинга «РИД-Эксперт РА»;

Dummy_comp - фиктивную переменную раскрытия денежного вознаграждения по компонентам, принимающую значение 1, если вознаграждение раскрывается по компонентам, и 0 в противном случае;

Dummy_option - фиктивную переменную вознаграждения топ-менеджмента и совета директоров в виде опционов на покупку акций, принимающую значение 1 , если в официальных источниках компании упоминаются опционные программы по вознаграждению топ-менеджмента и совета директоров, действующие в данном конкретном году, и 0 в противном случае.

Для получения этих данных нами использовались следующие источники:

- годовые отчеты компаний (практически только в них раскрывалась информация о наличии независимых директоров в составе совета директоров);

- отчеты по IAS/GAAP (для получения информации по фундаментальным факторам создания стоимости компаний);

- ежеквартальные отчеты эмитента (для получения информации о вознаграждении топменеджеров и совета директоров, а также о доли в уставном капитале, принадлежащей топ-менеджменту и совету директоров);

- официальные сайты компаний;

- результаты рейтинга «РИД-Эксперт РА».

\section{Интерпретация результатов исследования}

Полученные результаты позволяют сделать вывод, что для описания наших данных лучше всего использовать модель со случайными эффектами, которая в конечном виде будет выглядеть следующим образом:

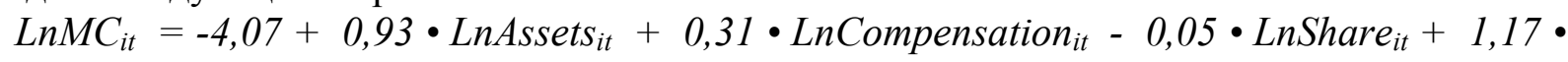
Inddirect $_{i t}+0,45 \cdot$ Dummy_option $_{i t}+v_{i t}$.

Выбор модели со случайными эффектами очень важен, поскольку на основе ее результатов мы можем сделать выводы не только относительно компаний, попавших в данную выборку, но относительно всей большой генеральной совокупности, то есть всех крупнейших российских компаний.

Характерно, что результаты модели со случайными эффектами агрегируют в себе Выпуск \#4(8), 2008

() Электронный журнал Корпоративные Финансы, 2008 
результаты двух других моделей.

При этом важно отметить, что в данном исследовании мы ставили задачу аппроксимации степени влияния, а не точной количественной оценки вознаграждения.

Таким образом, мы подтверждаем следующие три гипотезы:

H1: в определенной степени денежное вознаграждение топ-менеджмента и совета директоров влияет в среднесрочной перспективе через механизм принятия решений на рыночную капитализацию компании, и это влияние положительно и значимо.

H2: вознаграждение топ-менеджмента и совета директоров в виде опциона на покупку акций положстельно влияет на рыночную капитализацию компании.

H4: доля независимых директоров в составе совета директоров положительно влияет на рыночную капитализацию компании.

И отклоняем три ниже перечисленные:

H3: раскрытие информации по компонентам вознаграждения топ-менеджмента и совета директоров положительно влияет на рыночную капитализацию компании.

H5: доля в уставном капитале компании, принадлежащая топ-менеджерам и совету директоров, положительно влияет на рыночную капитализацию компании.

H6: интегральный показатель качества корпоративного управления положительно влияет на рыночную капитализацию компании.

Подтверждение первой гипотезы мы находим в выводах большинства исследований.

Так, в определенной степени вознаграждение топ-менеджеров и совета директоров крупных российских компаний действительно позволяет частично элиминировать конфликт интересов между менеджерами и акционерами. Соответственно вознаграждение опосредованно, через механизм принятия решений топ-менеджментом и советом директоров, влияет на ожидания рынка, что в свою очередь отражается на рыночной стоимости компании в той степени, в какой это возможно.

Что касается небольшого коэффициента при переменной логарифма денежного вознаграждения топ-менеджмента и совета директоров, можно предположить, что развитие систем мотивации топ-менеджмента и совета директоров на примере российских компаний создаст дополнительные резервы прироста рыночной капитализации компании, пока эти возможности недоиспользованы.

Подтверждение второй гипотезы тоже соответствует выводу большинства исследований, особенно тех, которые занимались изучением влияния опционных программ на деятельность западных компаний в период начала их использования.

Так, вознаграждение топ-менеджеров и совета директоров крупных российских компаний в виде опционов на покупку акций ведет к сокращению разделения между собственником и менеджером, то есть к снижению агентских издержек.

Четвертая гипотеза, хотя и не сообразуется с противоречивыми выводами исследований, проведенных в развитых странах, зато целиком совпадает с выводами исследователей развивающихся стран.

Так, наличие независимых директоров в составе совета директоров крупной российской компании обеспечивает более эффективные решения и сбалансированность интересов различных стейкхолдеров.

Гипотезы, которые мы отклонили, тоже заслуживают особого внимания.

Начнем обсуждение нашей пятой гипотезы, касающейся доли в уставном капитале компании, принадлежащей топ-менеджменту и совету директоров.

Гипотезу о наличии положительной связи между рыночной капитализацией компании и долей в уставном капитале, принадлежащей топ-менеджменту и совету директоров, мы не просто отклонили, но обнаружили между ними обратную связь. С чем это может быть связано?

Во-первых, на наш взгляд, это связано с очень частой сменой команды топменеджмента и совета директоров. Так, в период с 2004-го по 2006 год, когда рыночная капитализация всех компаний росла, топ-менеджеры и члены совета директоров, владеющие 
достаточным количеством акций, наоборот, покидали свои посты, и на смену им приходили либо независимые директора, либо топ-менеджеры, не обладающие акциями компании.

Во-вторых, далеко не любая доля в уставном капитале приводит к росту рыночной капитализации; реальный, а не номинальный собственник, как правило, заинтересован в долгосрочном росте. Больший размер доли в уставном капитале, и, в частности, блокирующий пакет, вероятнее всего, будут обуславливать искомую взаимосвязь.

Стоит отметить, что наличие отрицательного влияния доли в уставном капитале компании, принадлежащей топ-менеджменту и совету директоров, на рыночную капитализацию не противоречит выводу о наличии положительного влияния вознаграждения топ-менеджмента и совета директоров в виде опционов на покупку акций на рыночную капитализацию компании. Во-первых, не стоит забывать о существовании фантомных опционов. Во-вторых, даже если эти опционы реальные, оба вывода могут быть объединены в один, заключающийся в наличии некой оптимальной доли в уставном капитале компании, принадлежащей топ-менеджменту и совету директоров, как уже было сказано выше.

Что касается таких параметров, как раскрытие информации по компонентам вознаграждения топ-менеджеров и совета директоров и интегральный показатель качества корпоративного управления - рейтинг «РИД-Эксперт РА», то они не оказывают никакого влияния на рыночную капитализацию компании. Относительно незначимости коэффициента при рейтинге корпоративного управления «РИД-Эксперт РА» можно сказать, что, видимо, данный рейтинг также нуждается в доработке: в частности, у него слишком узкая шкала оценок. Возможно, если бы она была шире, мы бы удостоверились в нашей шестой гипотезе.

Коэффициент при раскрытии информации по компонентам вознаграждения топменеджеров и совета директоров во всех трех регрессиях имеет разные знаки. К тому же он везде статистически не значим. Все это говорит о том, что рынок пока не реагирует на раскрытие информации по компонентам вознаграждения, так как либо раскрываемой информации недостаточно, либо она в ряде случаев воспринимается рынком как недостоверная.

Таким образом, можно сказать, что система вознаграждения топ-менеджмента и совета директоров является полем возможностей компании. На базе данного и ряда других исследований возможно проведение ряда дополнительных исследований для целей оптимизации. Так, с одной стороны, наблюдается положительное влияние вознаграждения топ-менеджмента и совета директоров через механизм принятия стратегических, управленческих и финансовых решений. С другой - возникают противоречия относительно компонентов вознаграждения, так как раскрываемая информация ничего не привносит в стоимость компании. Очевидно, что в уставном капитале существует определенная оптимальная доля ключевых лиц компании, которая обезопасит компанию от столь критической с точки зрения разрушения финансового благополучия «игры со стоимостью». Для дальнейших исследований важно расширить диапазон и разнообразить интегральные рейтинги корпоративного управления на российском рынке.

\section{Список литературы}

1. Байбурина Э., Ивашковская И. Роль интеллектуального капитала в создании стоимости крупных российских компаний // Вестник финансовой академии. 2007. № 4.

2. Грачева М., Карапетян Д. Корпоративное управление в России // Управление компанией, 2004. № 1.

3. Детальные результаты исследования «Роль независимых членов советов директоров в управлении российскими предприятиями». Сайт российского института директоров: http://rid.ru.

4. Ивашковская И., Пономарева М., Сеттлз А. Деятельность советов директоров и 
стратегическая эффективность // Проблемы теории и практики управления. 2007. № 8.

5. Ивашковская И., Ращупкин А., Осипов Я. Советы директоров и корпоративная эффективность в переходной экономике: исследование на базе национального рейтинга «РИД-Эксперт РА. Сборник докладов «Корпоративное управление и устойчивое развитие бизнеса». М.: Изд. дом ГУ ВШЭ, 2008.

6. Информация о рейтинге «РИД-Эксперт РА», http://www.rid.ru/rating/information.

7. Информация о рейтинге «РИД-Эксперт РА». http://www.rid.ru/rating/informacionnaja_spravka.

8. Исследование «Готовность российских компаний к практическому внедрению рекомендаций Кодекса корпоративного поведения»: http://www.amr.ru/research/analit/detail.php?ID=4184.

9. Ковалев Д. Парк EVA-вского периода //Комп\&ньон. 2007. № 8 . http://strategicmanagement.ru/eva_park.html.

10. Рачинский А. Корпоративное управление и рыночная стоимость российских компаний. Центр экономических и финансовых исследований и разработок, 2003.

11. Родионов И., Старюк П. Стратегическое управление стоимостью компании как основная задача корпоративного управления. Сборник докладов «Корпоративное управление и устойчивое развитие бизнеса». М.: Изд. дом ГУ ВШЭ, 2008.

12. Abowd J. Does Performance-Based Managerial Compensation Affect Corporate Performance? //Industrial and Labor Relations Review. 1990. Vol. 43.

13. Adjaodi F., Zeghal D., Andaleeb S. The Effect of Board Quality on Perfopmance: A Study of Canadian Firms // Corporate Governance. 2007. Vol. 15.

14. Agrawal A., Knoeber C. Firm Performance and Mechanisms to Control Agency Problems between Managers and Shareholders // Financial and Quantative Analysis. 1996. Vol. 7.

15. Barnhart S., Rosenstein S. Board Composition, Managerial Ownership, and Firm Performance: An Empirical Analysis //Financial Review. 1998. Vol. 1.

16. Baum C., Sarver L., Strickland T. EVA, MVA and CEO Compensation: Further Evidence // American Business Review/ 2004. Vol. 22.

17. Bhagat S., Black B. The Uncertain Relationship Between Board Composition and Firm Performance // Business Lawyer. 1999. Vol. 54.

18. Black B. The Corporate Governance Behavior and Market Value of Russian Firms //Emerging Markets Review. 2001. Vol. 2.

19. Black B., Jang H., Kim W. Does Corporate Governance Predict Firms' Market Values? Evidence from Korea // Journal of Law, Economics \& Organization. 2005. Vol. 23.

20. Black B., Love I., Rachinsky A. Corporate Governance Indices and Firms' Market Values: Time Series Evidence from Russia // Emerging Markets Review. 2006. Vol. 2..

21. Brown L., Caylor M. Corporate Governance and Firm Performance // Working paper. 2004. http://ssrn.com/abstract=586423.

22. Desay A., Fatemi A., Katz J. Wealth Creation and Managerial Pay: MVA and EVA as Determinantes of Executive Compensation // Working paper. 1999. http://www.sciencedirect.com/science?_ob=MImg\&_imagekey=B6W4F-489.

23. Dhaliwal D., Salamon G., Smith E. The Effect of Öwner Versus Management Control on the Choice of Accounting Methods'//Journal of Accounting and Economics. 1982. Vol. 4.

24. Evans J., Evans R. An Examination of Economic Value Added and Executive Compensation // Working paper. 2003. http://ssrn.com/abstract=313974.

25. Ferris S., Stephen P., Hagannathan M., Pritchard A. Too Busy to Mind the Business? Monitoring by Directors with Multiple Board Appointments // Working paper. 2002. http:/papers.ssrn.com/abstract $=167288$.

26. Griffith J., Najand M. REIT Executive Compensation, Performance, and Management Power: Evidence from Panel Data // Working paper. 2006. http://ssrn.com/abstract=980663.

27. Hermalin B.,Weisbach M. The Determinants of Board Composition // RAND Journal of 
Economics. 1988. Vol. 19.

28. Leblanc R., Gillies J. Inside the Boardroom: How Boards Really Work and the Coming Revolution in Corporate Governance. Wiley, 2005.

29. Lambert R., Larcker D. Executive Compensation Effects of Large Corporate Acquisitions // Journal of Accounting and Public Policy. 1987. Vol. 6.

30. Lawrence J., Stapledon G. Is Board Composition Important? A Study of Listed Australian Companies, 1999 // Working Paper. 1999. http://ssrn.com/abstract=193528.

31. Masson R. Executive Motivations, Earnings, and Consequent Equity Performance // Journal of Political Economy. 1971. Vol. 79.

32. McConnell J., Servaes H. Additional Evidence on Equity Ownership and Corporate Value // Journal of Financial Economics. 1990. Vol. 27.

33. Mehran H. Executive Compensation Structure, Ownership and Firm Performance //Financial Economics.1995. Vol. 38.

34. Morck R., Shleifer A., Vishny R. Management Ownership and Market Valuation: An Empirical Analysis // Journal of Financial Economics. 1988. Vol. 20.

35. Murphy K. Executive Compensation // Working paper. 1998. http://ssrn.com/abstract $=163914$.

36. Reddy L., Reddy R. Performance Evaluation, Economic Value Added and Managerial Behaviour, Business Review. 2006. Vol. 1.

37. Rosenstein S., Wyatt J. Outside Directors, Board Independence, and Shareholder Wealth // Financial Economics. 1990. Vol. 26.

38. Sheikholeslami M., EVA, MVA, and CEO Compensation // American Business Review. 2001. Vol. 19.

39. Smith B., Amoako-Adu B. Relative Prices of Dual Class Shares // Financial and Quantative Analysis. 1995. Vol. 30.

40. Vance S. Corporate Governance: Assessing Corporate Performance by Boardroom Attributes //Business Research. 1978. Vol. 59.

41. Yermack D. Higher Market Valuation of Companies with a Small Board of Directors // Financial Economics. 1996. Vol. 40. 